\title{
Characterization of fatty acid modifying enzyme activity in staphylococcal mastitis isolates and other bacteria
}

Thea Lu', Joo Youn Park ${ }^{4}$, Kelleen Parnell ${ }^{2}$, Larry K Fox ${ }^{3}$ and Mark A McGuire ${ }^{2^{*}}$

\begin{abstract}
Background: Fatty acid modifying enzyme (FAME) has been shown to modify free fatty acids to alleviate their bactericidal effect by esterifying fatty acids to cholesterol or alcohols. Although it has been shown in previous studies that FAME is required for Staphylococcus aureus survival in skin abscesses, FAME is poorly studied compared to other virulence factors. FAME activity had also been detected in coagulase-negative staphylococci (CNS). However, FAME activity was only surveyed after a bacterial culture was grown for $24 \mathrm{~h}$. Therefore if FAME activity was earlier in the growth phase, it would not have been detected by the assay and those strains would have been labeled as FAME negative.
\end{abstract}

Results: Fifty CNS bovine mastitis isolates and several S. aureus, Escherichia coli, and Streptococcus uberis strains were assayed for FAME activity over $24 \mathrm{~h}$. FAME activity was detected in 54\% of CNS and $80 \%$ S. aureus strains surveyed but none in E. coli or S. uberis. While some CNS strains produced FAME activity comparable to the lab strain of S. aureus, the pattern of FAME activity varied among strains and across species of staphylococci. All CNS that produced FAME activity also exhibited lipase activity. Lipase activity relative to colony forming units of these CNS decreased over the $24 \mathrm{~h}$ growth period. No relationship was observed between somatic cell count in the milk and FAME activity in CNS.

Conclusions: Some staphylococcal species surveyed produced FAME activity, but E. coli and S. uberis strains did not. All FAME producing CNS exhibited lipase activity which may indicate that both these enzymes work in concert to alter fatty acids in the bacterial environment.

Keywords: Fatty acid modifying enzyme, Lipase, Coagulase-negative staphylococci

\section{Background}

Fatty acid modifying enzyme (FAME) was first described by Mortensen et al. [1] while studying abscesses caused by Staphylococcus aureus. It was found that culture filtrates of S. aureus contained an extracellular enzyme that counteracted the bactericidal activity of lipids within abscesses. When fatty acid samples were incubated with FAME in the presence of ethanol, ethyl esters were produced. The FAME enzyme acts by esterifying free fatty acids to short chain primary alcohols and cholesterol, with cholesterol being the preferred substrate [1] (Figure 1).

\footnotetext{
* Correspondence: mmcguire@uidaho.edu

${ }^{2}$ Department of Animal and Veterinary Sciences, University of Idaho, Moscow, USA

Full list of author information is available at the end of the article
}

While FAME activity can be detected experimentally, the FAME protein and its corresponding gene have yet to be identified.

In an abscess, microbicidal fatty acids are part of the first line of defense for the host against invading pathogens [2]. Staphylococcal FAME, however, is inhibited by glycerides and it is thought that to alleviate this inhibition, S. aureus also produces lipase which liberates the free fatty acids from the glyceride backbone so that FAME can further esterify the free fatty acids [3]. Previous studies have shown that about $80 \%$ of the staphylococcal strains that produce lipase also produce FAME. Strains that did not produce both of these enzymes were more sensitive to free fatty acids. Long and colleagues [4] speculated that survival in abscesses and pathogenesis would require these two enzymes.

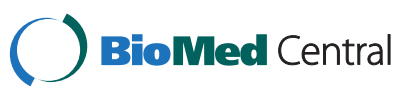




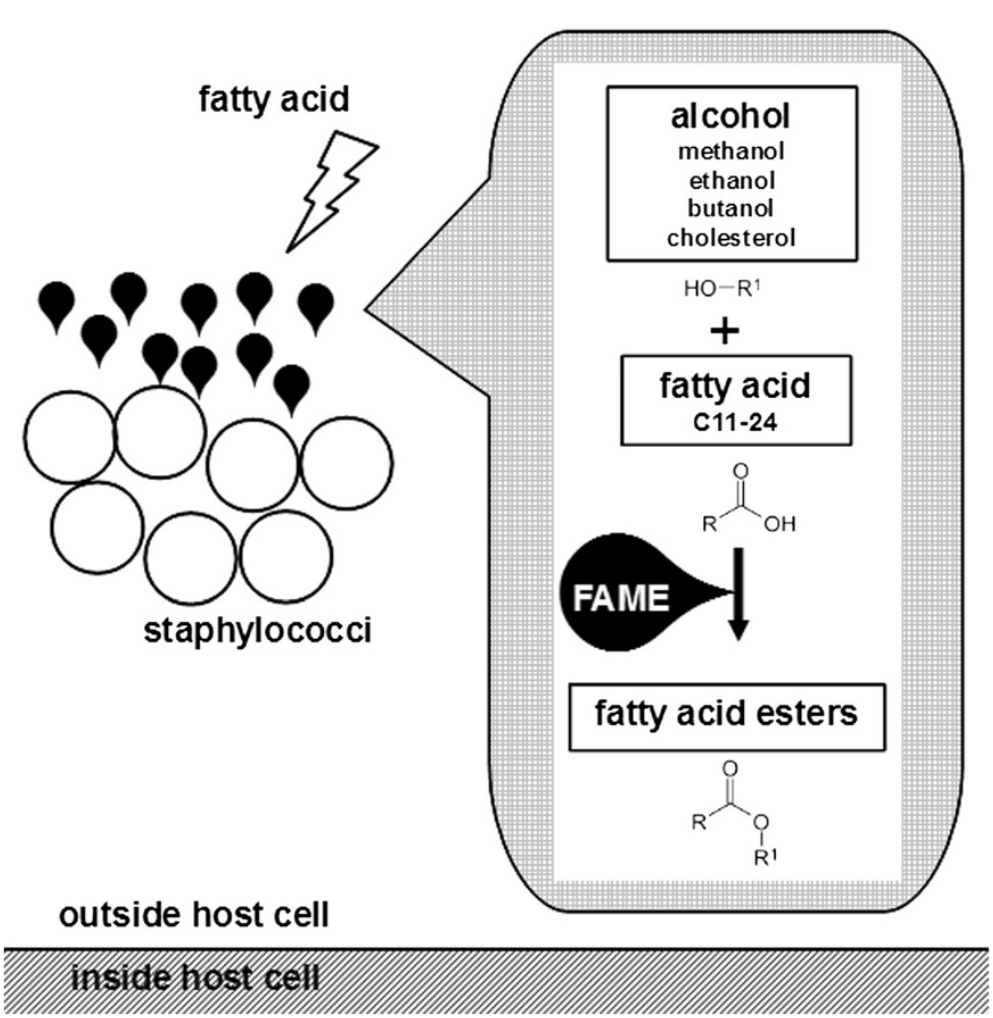

Figure 1 Esterification of fatty acids by fatty acid modifying enzyme (FAME). Staphylococci (open circles) colonize the host and block the bactericidal effects of fatty acids (open bolt) by secreting FAME (solid balloons) which esterifies fatty acids to alcohol esters.

Previously, FAME activity was assayed in a selected number of other staphylococci including coagulasenegative staphylococci (CNS). However, FAME activity was only surveyed after CNS were grown for $24 \mathrm{~h}$ [4] and in one strain of S. epidermidis for up to $12 \mathrm{~h}$ [5]. Therefore if FAME activity occurred earlier in the growth phase but the enzyme producing this activity was degraded before the assayed time point, it would not have been detected by the assay and those strains would have been labeled as FAME negative. S. aureus strains that had been previously studied included the lab strain S. aureus RN6390 and clinical isolates found in intraperitoneal abscesses [1,2]. However, staphylococci clinically important in bovine mastitis have yet to be characterized for FAME activity. We hypothesized that FAME activity is dependent on staphylococcal strain and is related to virulence.

\section{Results}

Fifty CNS strains isolated from bovine milk were assayed for FAME activity over $24 \mathrm{~h}$. Bacterial growth assessed by optical density (OD) and colony forming units (CFU) were found to be similar in all strains within species. In our growth conditions, cultures reached stationary phase after 8-12 h. FAME activity was detected in at least one strain of each CNS species except for Staphylococcus equorum, Staphylococcus gallinarum, and Staphylococcus sciuri. Out of the 50 CNS strains surveyed, 27 (54\%) strains had detectable FAME activity. Bovine mastitis isolates of Escherichia coli and Streptococcus uberis did not produce detectable FAME activity over $24 \mathrm{~h}$ of growth. All $S$. aureus strains surveyed except one produced detectable FAME activity (Table 1).

Different $S$. aureus strains exhibited different patterns of FAME activity. In the laboratory strain $S$. aureus RN6390, FAME activity increased with bacterial growth; activity reached a plateau by $16 \mathrm{~h}$ at $5 \%$ esterification of oleic acid to butyl oleate compared to a standard of butyl stearate (FAME activity) per $\log$ CFU and remained stable for the rest of stationary phase to $24 \mathrm{~h}$ (Figure 2). Both $S$. aureus Newman and $S$. aureus USA300 reached maximal FAME activity at $24 \mathrm{~h}$ (12.5\% and $21 \%$ FAME activity/log CFU, respectively). S. aureus MN8 peaked at $16 \mathrm{~h}$ with $18 \%$ esterification per $\log$ CFU. The bovine mastitis isolate $S$. aureus Novel reached a maximum FAME activity of $7 \%$ esterification per $\log$ CFU at $8 \mathrm{~h}$, but the activity decreased at $20 \mathrm{~h}$ with very little activity $(0.7 \%)$ detected at $24 \mathrm{~h}$. The other bovine mastitis isolate tested, S. aureus Newbould 305, did not have any detectable FAME activity over $24 \mathrm{~h}$.

The pattern of FAME activity over a $24 \mathrm{~h}$ period exhibited by CNS was different among species and strains 
Table 1 FAME activity in tested bacteria

\begin{tabular}{|c|c|c|c|}
\hline Species & $\begin{array}{l}\text { No. of strains } \\
\text { tested }\end{array}$ & $\begin{array}{l}\text { No. of strains } \\
\text { with FAME } \\
\text { activity (\%) }\end{array}$ & $\begin{array}{l}\text { Relative range } \\
\text { of FAME activity } \\
\text { at } 25 \mathrm{~h}\end{array}$ \\
\hline S. aureus & 6 & $5(83)$ & $0-187^{*}$ \\
\hline Escherichia coli & 2 & $0(0)$ & 0 \\
\hline Streptococcus uberis & 1 & $0(0)$ & 0 \\
\hline \multicolumn{4}{|c|}{ Coagulase Negative Staphylococci } \\
\hline S. capitis & 1 & $1(100)$ & $19-47^{*}$ \\
\hline S. caprae & 3 & $3(100)$ & $13-42^{*}$ \\
\hline S. chromogenes & 15 & $4(27)$ & $0-22^{*}$ \\
\hline S. epidermidis & 2 & $2(100)$ & $4-6^{*}$ \\
\hline S. equorum & 1 & $0(0)$ & 0 \\
\hline S. gallinarum & 1 & $0(0)$ & 0 \\
\hline S. haemolyticus & 8 & $4(50)$ & $0-21^{*}$ \\
\hline S. hominis & 1 & $1(100)$ & $1-10^{*}$ \\
\hline S. hyicus & 3 & $2(67)$ & $0-7^{*}$ \\
\hline S. sciuri & 2 & $0(0)$ & 0 \\
\hline S. simulans & 5 & $5(100)$ & $10-35^{*}$ \\
\hline S. succinus & 2 & $1(50)$ & $0-5^{*}$ \\
\hline S. xylosus & 6 & $4(67)$ & $0-172^{*}$ \\
\hline Total CNS & 50 & $27(54)$ & 0-172 \\
\hline
\end{tabular}

"Percent esterification compared to a standard with significant activity $P<0.05$ from negative control.

within species. FAME activity increased in Staphylococcus capitis throughout its growth and peaked in stationary phase at $20 \mathrm{~h}$ (Figure 3). S. capitis produced appreciable FAME activity from 16 to $24 \mathrm{~h}$ with $15 \%$ esterification per log CFU at 20 h. By contrast, Staphylococcus hominis FAME activity did not rise above $0.5 \%$ at any point during the $24 \mathrm{~h}$ culture.
All Staphylococcus caprae strains examined started producing FAME activity by $8 \mathrm{~h}$ (Figure 4 ). The three strains reached a maximum activity by 16,20 , or $24 \mathrm{~h}$. The $S$. caprae strains surveyed had FAME activity peaking around $1.7-5 \%$ by $24 \mathrm{~h}$. Four out of 15 Staphylococcus chromogenes strains produced FAME activity; activity was greatest $20-24 \mathrm{~h}$ in culture (up to $2.7 \%$ esterification) with one strain also producing some activity (0.6\% esterification per log CFU) from 4 to $8 \mathrm{~h}$ (Figure 5). All Staphylococcus epidermidis (Figure 6) strains surveyed produced increasing FAME activity up to $20 \mathrm{~h}$ of culture with maximum activity less than $1 \%$ esterification per log CFU. Four Staphylococcus haemolyticus strains had no detectable FAME activity, however, four other strains produced detectable FAME activity beginning at $12 \mathrm{~h}$ (Figure 7). S. haemolyticus strains exhibited considerable variation in the pattern of FAME activity with maximal activity at different times of culture and ranging from 2.5 to $8 \%$ (Figure 8). One strain of Staphylococcus hyicus produced less than 0.5\% FAME activity per $\log$ CFU over the entire growth period with just above the detectable limit at $16 \mathrm{~h}$, while another strain produced a detectable amount of FAME activity at $4 \mathrm{~h}$ with activity increasing after $16 \mathrm{~h}$ up to $1 \%$ at $24 \mathrm{~h}$ (Figure 8). The FAME producing strains of Staphylococcus simulans showed several patterns of FAME activity throughout culture (Figure 9). These S. simulans strains started producing detectable FAME activity at $4 \mathrm{~h}$. Two strains produced relatively consistent FAME activity (1$2 \%$ ) between 4 and $24 \mathrm{~h}$. Two other strains of S. simulans had FAME activity increase above 3\% between 12 or $16 \mathrm{~h}$. One strain of S. simulans had peak FAME activity of $6.8 \%$ at $20 \mathrm{~h}$. At $24 \mathrm{~h}$, FAME activity in S. simulans strains ranged from 1 to $4 \%$. One strain of

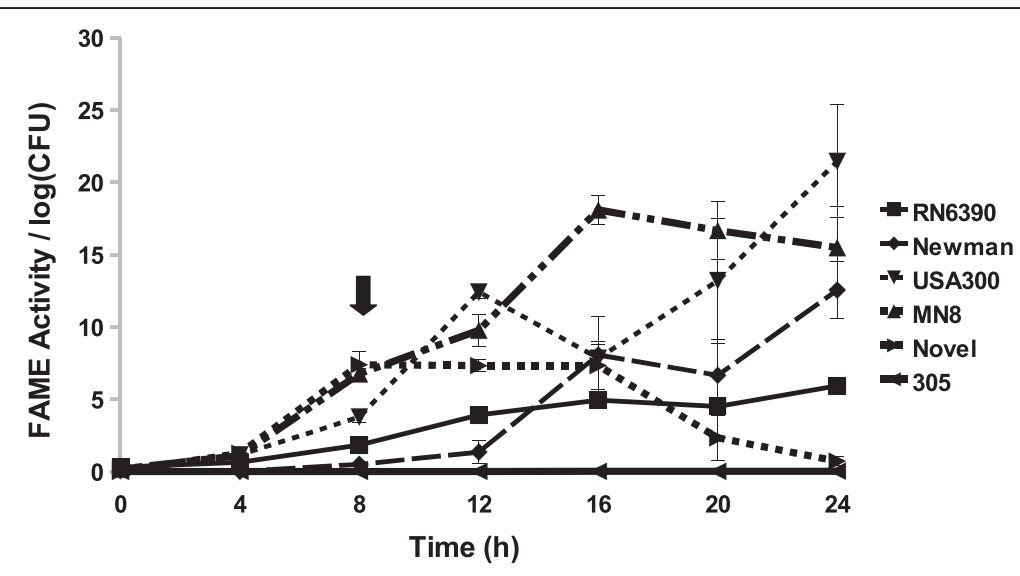

Figure 2 Most surveyed S. aureus strains produce FAME activity. S. aureus strains RN6390, Newman, USA300, MN8, Novel, and Newbould 305 were assayed for FAME activity/log CFU over $24 \mathrm{~h}$. CFUs were generally the same among the strains with the beginning of stationary phase indicated by the arrow. Results are the average of three experiments. Vertical bars represent standard error of the observation; if no bar is apparent the standard error is smaller than the symbol. Detectable activity for RN6390, Newman, USA300, MN8, and Novel was seen at $8 \mathrm{~h}(P<0.05)$ 


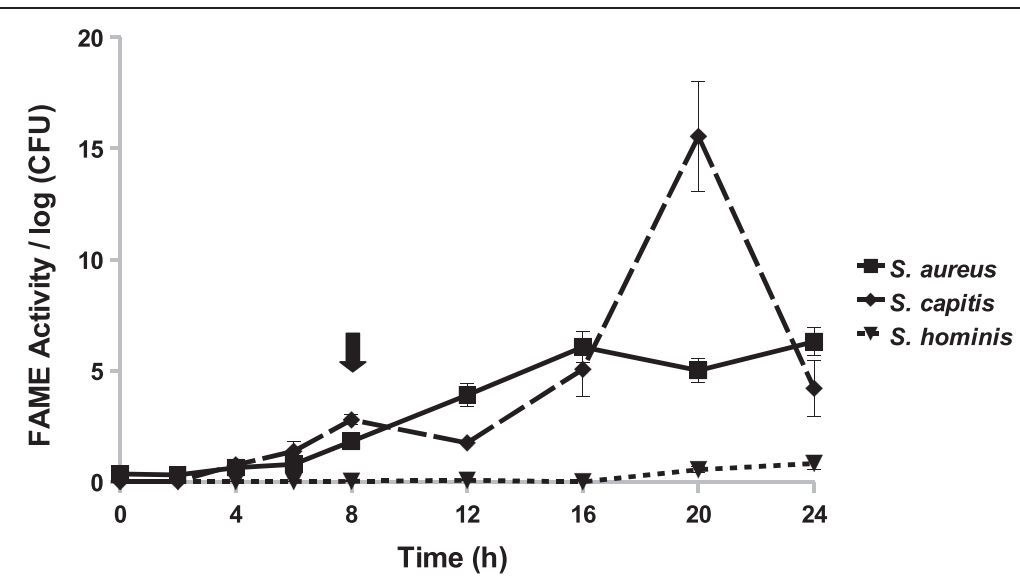

Figure 3 S. aureus, S. capitis, and S. hominis exhibit different patterns FAME activity. S. aureus RN6390, S. capitis, and S. hominis were assayed for FAME activity/log CFU over $24 \mathrm{~h}$. CFUs were generally the same among the strains with the beginning of stationary phase indicated by the arrow. Results are the average of three experiments. Vertical bars represent standard error of the observation; if no bar is apparent the standard error is smaller than the symbol. Detectable activity for S. aureus and S. capitis was seen at $4 \mathrm{~h}$ and for S. hominis at $24 \mathrm{~h}(P<0.05)$.

Staphylococcus succinus (Figure 10) started producing detectable FAME activity at $8 \mathrm{~h}$ but activity never rose above $0.1 \%$. Staphylococcus xylosus was the CNS strain which produced the most FAME activity. In the four S. xylosus strains with FAME activity, activity was detected at $20 \mathrm{~h}$ (Figure 11). At $24 \mathrm{~h}$, FAME activity in these S. xylosus strains ranged from 1.7 to $20 \%$ esterification per log CFU.

Lipase activity per CFU was compared to FAME activity per CFU over $24 \mathrm{~h}$ in $27 \mathrm{CNS}$ strains with FAME activity. All CNS strains surveyed produced lipase activity. The strains showed decreased lipase activity (7.11 $\pm 0.52 \log$ of percent lipase activity divided by CFU; mean \pm SD) at $24 \mathrm{~h}$ compared to $0 \mathrm{~h}$. CNS strains that exhibited no detectable FAME activity produced a range of lipase activity (4.35 $\pm 4.81 \log$ of percent lipase activity divided by CFU; mean \pm SD). In strains that did produce FAME activity, the relationship between FAME and lipase activity was poor $\left(r^{2}=0.1\right)$ when activity for each were considered at each individual time point. However, the relationship of the mean FAME and lipase activities of all CNS with FAME activity at each time point correlated well $\left(r^{2}=0.92\right)$. Lipase activity per CFU decreased over the $24 \mathrm{~h}$ growth period.

No clear relationship was observed between FAME activity and somatic cell count (SCC) in milk for all CNS strains at $24 \mathrm{~h}$ (Figure 12). CNS strains with FAME activity less than $30 \%, 30-60 \%$, and greater than $60 \%$ had SCC (mean $x 1,000$ per $\mathrm{mL} \pm \mathrm{SD}$ ) of $331 \pm 585.2$, $1,010.1 \pm 237.4$, and $150.9 \pm 175.8$, respectively.

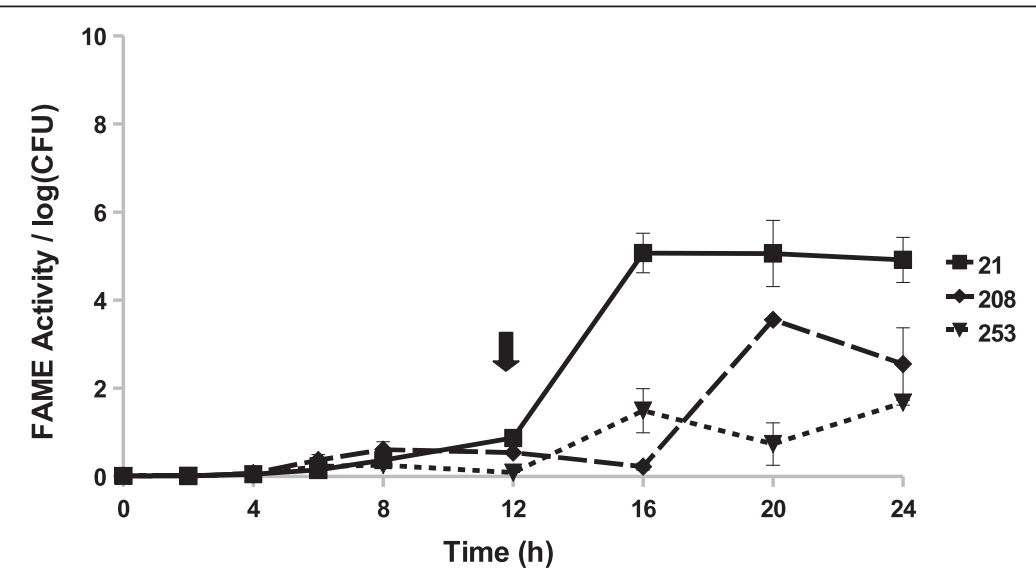

Figure 4 S. caprae produces FAME activity during stationary phase. S. caprae isolates were assayed for FAME activity/log CFU over $24 \mathrm{~h}$. CFUs were generally the same among the strains with the beginning of stationary phase indicated by the arrow. Results are the average of three experiments. Vertical bars represent standard error of the observation; if no bar is apparent the standard error is smaller than the symbol. Detectable activity for all $S$. caprae isolates was seen at $8 \mathrm{~h}(P<0.05)$. 


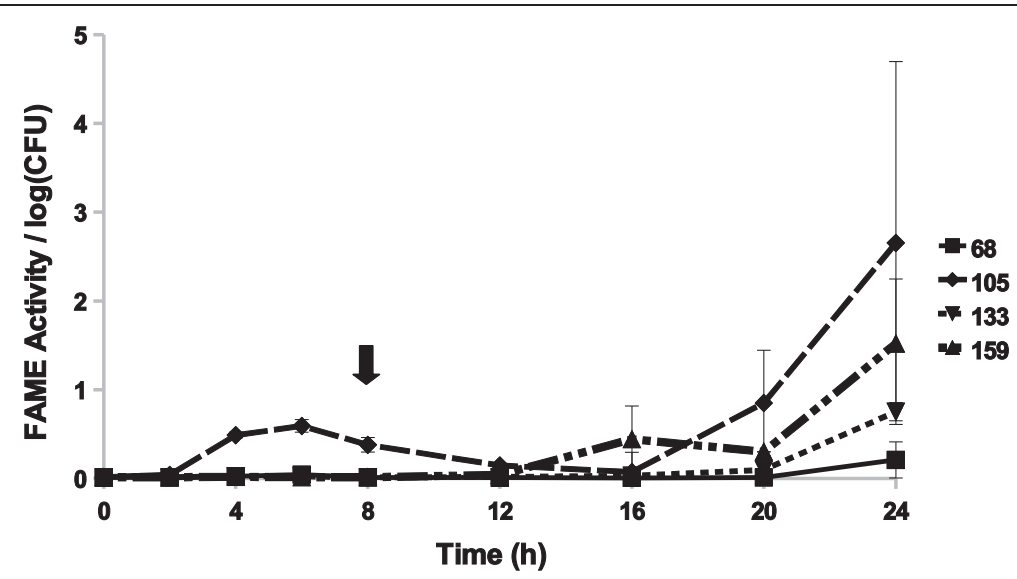

Figure 5 S. chromogenes isolates exhibit different patterns of FAME activity. S. chromogenes isolates were assayed for FAME activity/log CFU over $24 \mathrm{~h}$. CFUs were generally the same among the strains with the beginning of stationary phase indicated by the arrow. Results are the average of three experiments. Vertical bars represent standard error of the observation; if no bar is apparent the standard error is smaller than the symbol. S. chromogenes isolates had detectable FAME activity at $24 \mathrm{~h}(P<0.05)$.

\section{Discussion}

Staphylococcus aureus, S. epidermidis, and several other staphylococcal species have been shown to possess FAME activity [4], but this enzyme activity had not been assayed over a $24 \mathrm{~h}$ growth period or in other bacteria. We surveyed FAME activity in CNS isolated from bovine milk, S. aureus clinical isolates, and E. coli and $S$. uberis bovine mastitis isolates which served as negative controls and compared it to a laboratory strain of $S$. aureus. Using a quantitative assay of FAME activity, we found that the relative range of FAME activity varied across and within staphylococcal species over a $24 \mathrm{~h}$ growth period. No FAME activity was found in E. coli or $S$. uberis. In $S$. aureus, the highest FAME activity was found in strains originally isolated from human infections, S. aureus USA300, S. aureus MN8, and S. aureus
Newman. S. aureus Novel and S. aureus Newbould 305, bovine mastitis isolates which cause acute and chronic disease respectively [6], produced different patterns of FAME activity. There was also a difference in virulence between strains of $S$. aureus differing in FAME activity as tested in a murine model; $S$. aureus strains with FAME activity were able to persist longer in intraperitoneal abscesses than strains that did not produce this activity [1]. The differences in FAME activity observed in S. aureus Novel and S. aureus Newbould 305 and the severity of disease caused by each strain suggest that FAME may play a role in modulating virulence in bovine mastitis. Contrary to data collected by Long et al. [4], we found that some $S$. haemolyticus strains produced FAME activity. FAME activity varied in CNS; some did not rise above $\sim 10 \%$ esterification at any point during

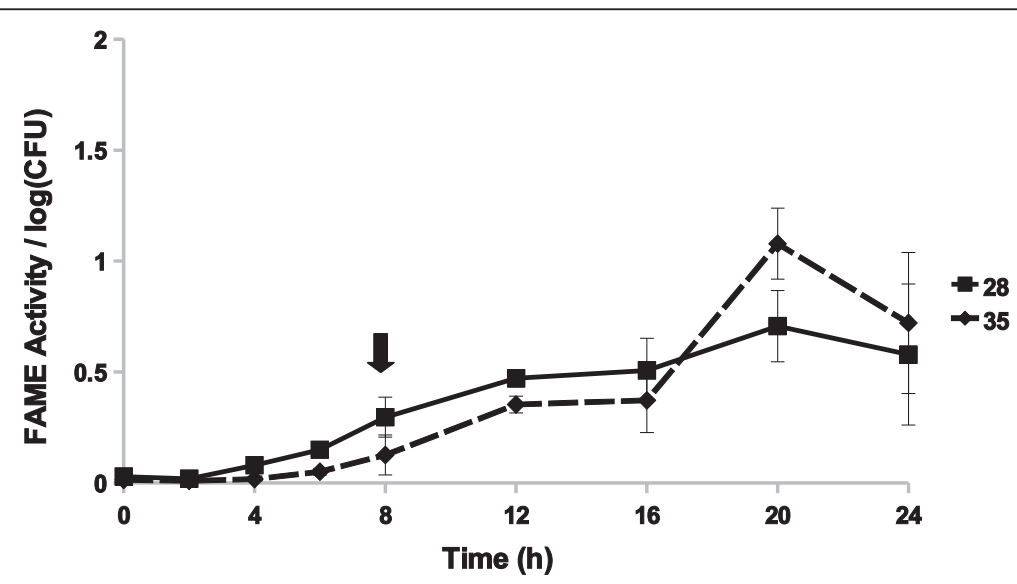

Figure 6 Two S. epidermidis isolates increase FAME activity over $\mathbf{2 4}$ h. S. epidermidis isolates were assayed for FAME activity/log CFU over $24 \mathrm{~h}$. CFUs were generally the same among the strains with the beginning of stationary phase indicated by the arrow. Results are the average of three experiments. Vertical bars represent standard error of the observation; if no bar is apparent the standard error is smaller than the symbol. FAME activity for all S. epidermidis isolates was detected at $6 \mathrm{~h}(P<0.05)$. 


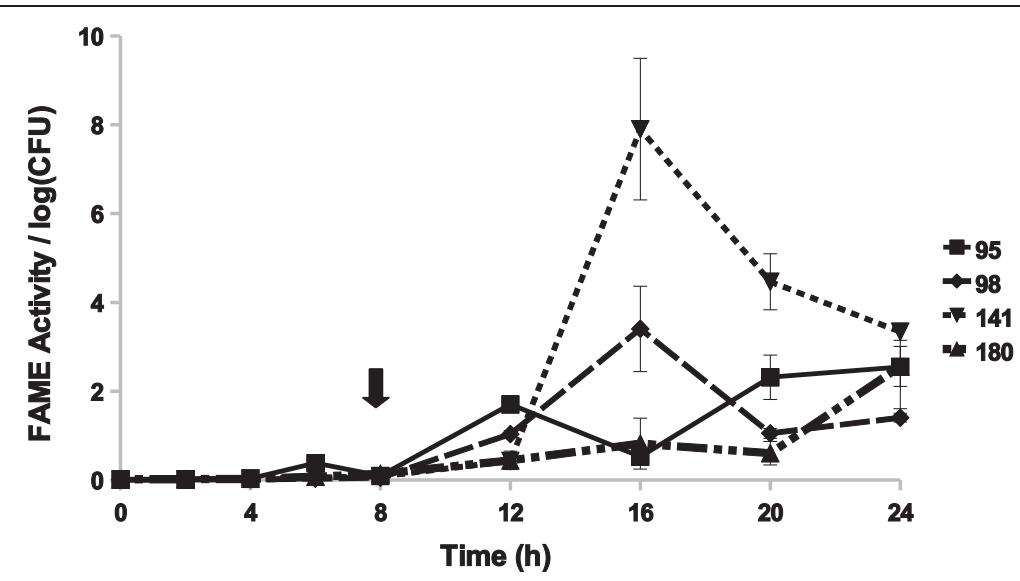

Figure 7 S. haemolyticus isolates exhibit different patterns of FAME activity. S. haemolyticus isolates were assayed for FAME activity/log CFU over $24 \mathrm{~h}$. CFUs were generally the same among the strains with the beginning of stationary phase indicated by the arrow. Results are the average of three experiments. Vertical bars represent standard error of the observation; if no bar is apparent the standard error is smaller than the symbol. FAME activity for all S. haemolyticus isolates was detected at $12 \mathrm{~h}(P<0.05)$.

the growth curve while others produced an appreciable amount or similar pattern of FAME activity like $S$. aureus. There were others such as S. equorum, S. gallinarum, and $S$. sciuri which produced no detectable FAME activity. However, this may not indicate that these species lack FAME activity, only that the isolates tested did not produce this activity under our assay conditions.

For the FAME positive CNS strains, FAME production peaked at different stages of growth. The discrepancy of FAME activity between different strains as well as species may be due to strain differences. The $a g r$ locus has high genetic variability in Staphylococcus species which would lead to a variation in regulation of any downstream staphylococcal products [7]. FAME activity has been shown to be regulated by agr and sar, global regulators known to modulate the production of virulence factors such as exotoxins [8,9]. Other regulators may also play a part in differences of FAME production in each strain. S. aureus RN6390, for example, is a natural deletion mutant of $r s b U$, a regulator of $\sigma^{\mathrm{B}}$, which controls bacterial response to acid stress [10]. The potential of $S$. aureus and CNS to cause a variety of diseases suggests a complex mechanism for pathogenesis which includes the regulatory input of environmental and host signals. The expression of staphylococcal virulence genes in vivo may also depend on distinct host signals from the target tissue [9]. Considering strain variability of $a g r$ alone, every strain could regulate FAME differently. As a result, FAME may not necessarily be produced by Staphylococcus spp. at a particular time point or growth condition. In our assay of several time points throughout a 24 h growth period, we found several Staphylococcus

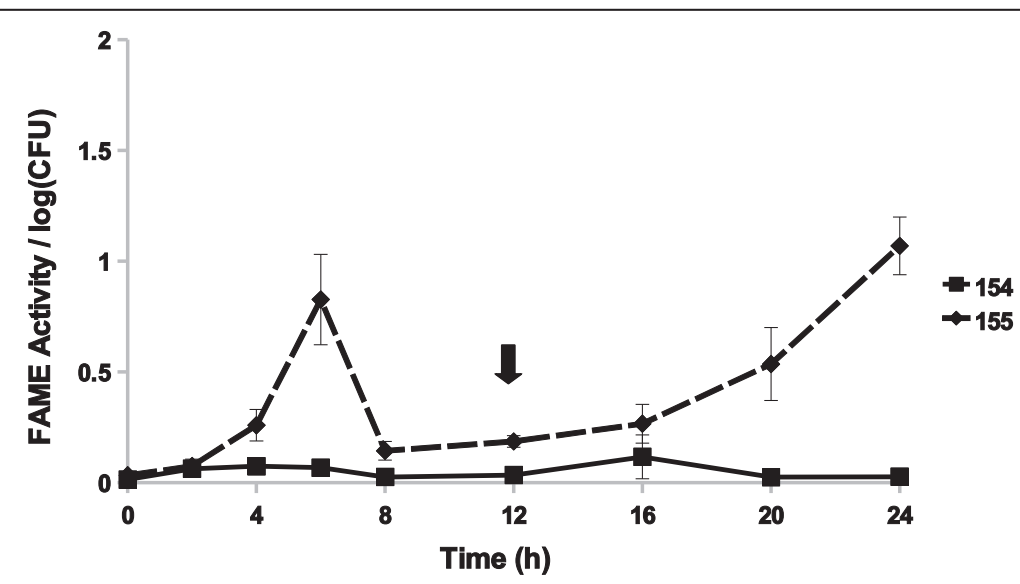

Figure 8 S. hyicus produces low FAME activity over $\mathbf{2 4}$ h. S. hyicus isolates were assayed for FAME activity/log CFU over 24 h. CFUs were generally the same among the strains with the beginning of stationary phase indicated by the arrow. Results are the average of three experiments. Vertical bars represent standard error of the observation; if no bar is apparent the standard error is smaller than the symbol. Both isolates had detectable activity at $4 \mathrm{~h}(P<0.05)$. 


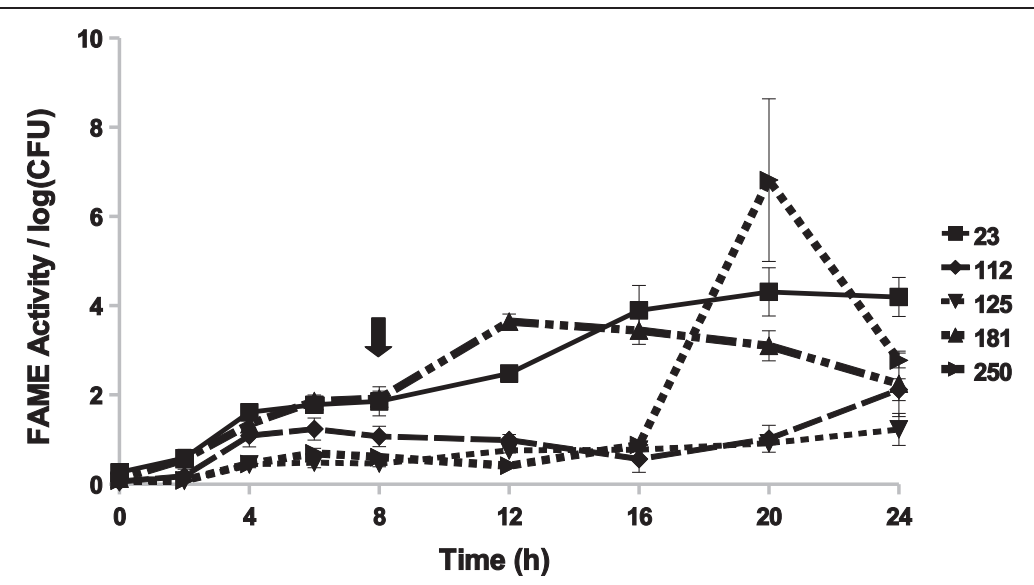

Figure 9 S. simulans isolates exhibit a range of patterns for FAME activity. S. simulans isolates were assayed for FAME activity/log CFU over $24 \mathrm{~h}$. CFUs were generally the same among the strains with the beginning of stationary phase indicated by the arrow. Results are the average of three experiments. Vertical bars represent standard error of the observation; if no bar is apparent the standard error is smaller than the symbol. FAME activity for all S. simulans isolates was detected at $4 \mathrm{~h}(P<0.05)$.

spp. exhibited maximum FAME production during time points earlier than $24 \mathrm{~h}$.

Lipase activity is produced by a group of enzymes found in a wide number of both Gram-negative and Gram-positive bacteria [11]. FAME has been hypothesized to work in concert with lipase to modify antimicrobial fatty acids in the host [4]. Kapral et al. [3] noted that FAME activity is optimal within abscesses at $\mathrm{pH} 6$ while lipase activity was optimal at $\mathrm{pH}$ 8. But more recent biochemical analyses reveal that some staphylococcal lipases are active over a broad $\mathrm{pH}$ range including pH 6 [11]. In our study, all strains observed with FAME activity also exhibited lipase activity lending support to this hypothesis that the presence of both these activities are required for fatty acid modification in the bacterial environment. We found however that CNS strains without FAME activity also had lipase activity. These bacteria were originally isolated from bovine milk where lipids are abundant [12,13]. Although lipase liberates potentially bactericidal fatty acids, the lipase-producing bacteria in milk may not be lipolytically active because most of the milk lipids are sequestered in fat globules [27]. A small increase in free fatty acids, however, is found in milk of cows with clinical mastitis [28]. Since staphylococci produce several lipases of which only a few have been characterized [11], the conditions in milk may not be optimal for lipase production in the CNS strains surveyed in this study. In CNS that did produce FAME activity, lipase and FAME activity per CFU decreased as bacterial growth progressed over $24 \mathrm{~h}$ although these enzyme activities increased in the overall culture.

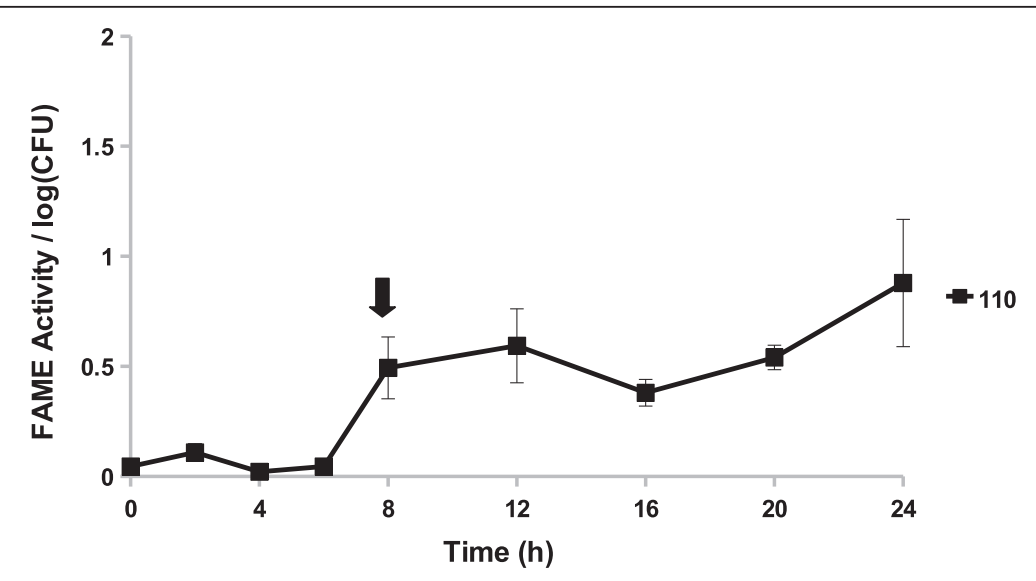

Figure 10 S. succinus produces low FAME activity over $\mathbf{2 4}$ h. Two S. succinus isolates were assayed but only one had detectable FAME activity. The FAME producing strain is shown for FAME activity/log CFU over $24 \mathrm{~h}$. CFUs were generally the same among the strains with the beginning of stationary phase indicated by the arrow. Results are the average of three experiments. Vertical bars represent standard error of the observation; if no bar is apparent the standard error is smaller than the symbol. FAME activity for $\mathrm{S}$. succinus was detected at $8 \mathrm{~h}(P<0.05)$. 


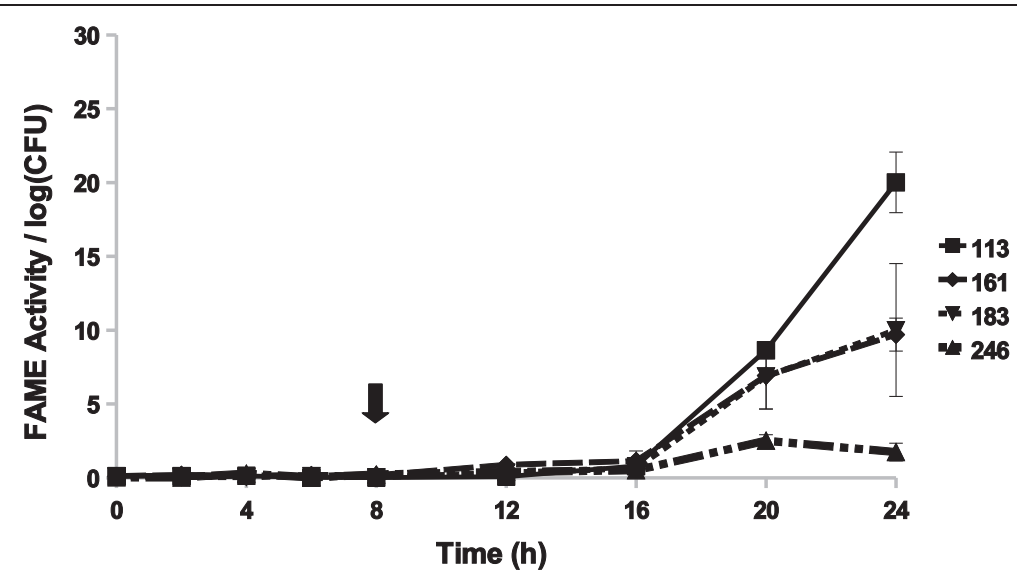

Figure 11 S. xylosus produces the highest FAME activity of all surveyed CNS strains. S. xylosus isolates were assayed for FAME activity/log CFU over $24 \mathrm{~h}$. CFUs were generally the same among the strains with the beginning of stationary phase indicated by the arrow. Results are the average of three experiments. Vertical bars represent standard error of the observation; if no bar is apparent the standard error is smaller than the symbol. S. xylosus isolates had detectable FAME activity at $20 \mathrm{~h}(P<0.05)$.

As one of the first lines of defense, the host recruits innate immune cells, such as neutrophils or polymorphonuclear leukocytes, to the site of inflammation [14]. Somatic cell count (SCC) in milk is used as a reliable indicator of inflammation in the mammary gland since it consists primarily of neutrophils and other leukocytes [15]. Previous observations suggested that FAME had a possible role in suppressing the host immune response [2]. However staphylococci associated with lower SCC varied in FAME production, and those with very high somatic cell counts (above 1,000,000 cells $/ \mathrm{mL}$ ) had less than 60\% FAME activity (Figure 12). This lack of association between FAME activity and SCC indicates that FAME in CNS plays little role in modulating the recruitment of immune cells but does not eliminate other possible functions. Modification of host lipids can also aid pathogenesis by disrupting host membranes, interfering with host signaling, and providing nutrients for the bacterium. In order to modify these lipids, pathogens can produce an array of enzymes that act on these

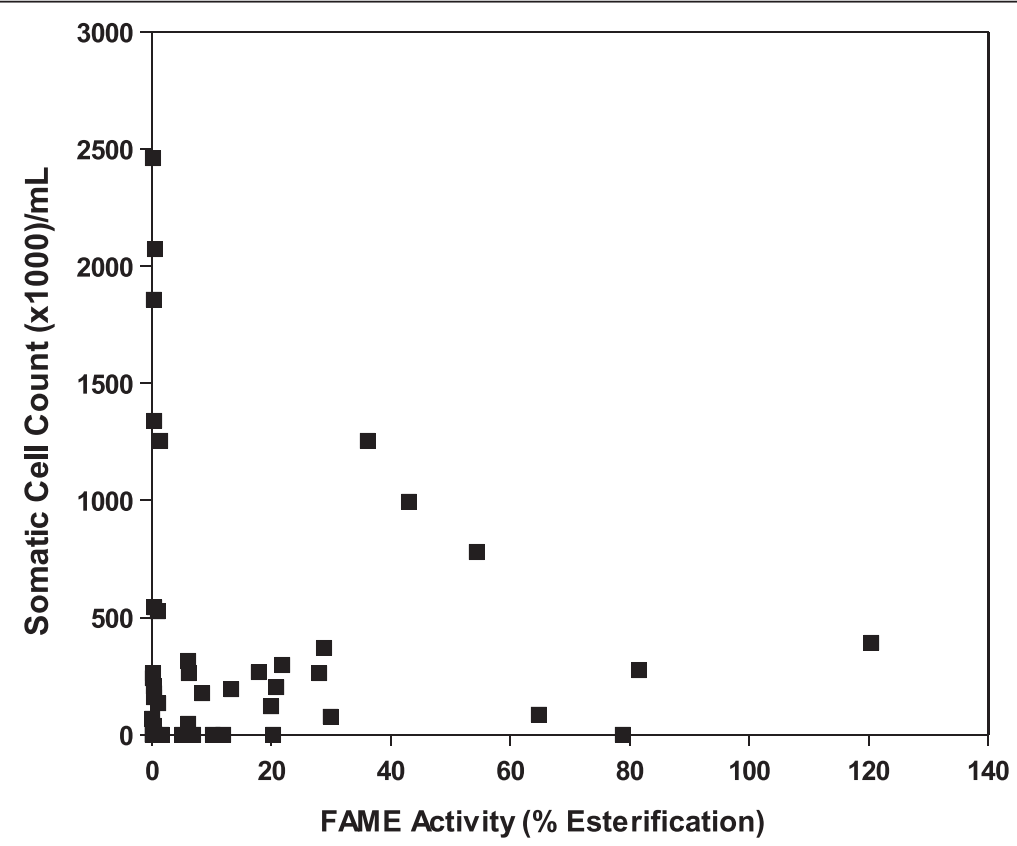

Figure 12 Staphylococci with FAME activity are compared to somatic cell counts in milk from commercial dairy cows. Somatic cell counts from the milk samples from which the CNS strains were isolated are compared with FAME activity assayed from $24 \mathrm{~h}$ culture supernatants. No clear relationship was observed between FAME activity and SCC in milk for all CNS strains $\left(r^{2}=0.01\right)$. 
substrates. Lipases have been shown to aid pathogens in immune evasion. Staphylococcal lipase decreases phagocytosis and intracellular killing by human granulocytes [16]. These lipases may also be involved in liberating host cell lipids for nutrient uptake [17]. Cholesterol is the preferred substrate for FAME [1] thus previously identified FAME negative bacteria could have been incorrectly characterized due to current methods which use butanol instead of cholesterol. Cholesterol can be manipulated by pathogens to influence host cell membrane fluidity, signaling pathways, and lipid raft composition. Helicobacter pylori modifies cholesterol to escape the immune system by inhibiting phagocytosis and T-cell activation [18]. Staphylococci may be using FAME for immunomodulation in a similar way by altering cholesterol homeostasis.

Bacteria with properties that make them impermeable to these antimicrobial lipids, such as thicker cell walls, may not require an enzyme like FAME [19]. However, FAME activity has only been surveyed in staphylococcal strains, E. coli, and S. uberis so it is unknown whether FAME is also widely found among bacterial species or is a uniquely staphylococcal enzyme. We have also shown that an assessment of FAME activity cannot rely solely on one time point since activity did not occur only during the stationary growth phase. Instead, FAME activity patterns vary across strains and species. To determine if FAME is unique to staphylococci, a comprehensive survey including more species and a variety of growth conditions would be required.

\section{Conclusions}

Some staphylococcal species surveyed produced FAME activity, but E. coli and $S$. uberis strains did not, suggesting that FAME activity may be limited to some staphylococcal species. For the FAME positive CNS strains, FAME production peaked at different stages of growth. The greatest FAME activity was found in strains originally isolated from human infections. S. aureus Novel, a strain associated with acute disease, produced detectable FAME activity while $S$. aureus Newbould 305, a strain of chronic disease, did not. The severity of disease caused by each of strain suggests that FAME may play a role in modulating virulence in bovine mastitis. All FAME producing CNS exhibited lipase activity which may indicate that both these enzymes work in concert to alter fatty acids in the bacterial environment.

\section{Methods}

\section{Bacterial strains}

The strains used in this study are listed in Table 2. The CNS strains were initially isolated from milk samples collected from cows with intramammary infection in dairies in Idaho and Washington and identified by $16 \mathrm{~S}$ ribosomal DNA sequencing [11]. Each strain was streaked on tryptic soy agar (TSA) from glycerol stocks and incubated overnight at $37^{\circ} \mathrm{C}$ before inoculating into $3 \mathrm{~mL}$ tryptic soy broth (TSB) and grown in a shaker incubator at $37^{\circ} \mathrm{C}$ and $250 \mathrm{rpm}$ for $16 \mathrm{~h}$. To determine the growth of each strain, the $16 \mathrm{~h}$ culture was inoculated into TSB at 1:100 in triplicate and grown at $37^{\circ} \mathrm{C}$ with shaking at $250 \mathrm{rpm}$ for $24 \mathrm{~h}$. Every $2 \mathrm{~h}$ from 0 to $8 \mathrm{~h}$ and every $4 \mathrm{~h}$ from 8 to $24 \mathrm{~h}$, growth of bacterial culture was determined by assaying optical density (OD) at $600 \mathrm{~nm}$ and by plating serial dilutions on TSA to determine colony forming units (CFU) for each strain in triplicate. Plates were incubated at $37^{\circ} \mathrm{C}$ for $15 \mathrm{~h}$ before determining bacterial growth.

\section{FAME activity assay}

Bacterial cultures were pelleted at $12,000 \times \mathrm{g}$ for $2 \mathrm{~min}$, and supernatant was removed for analysis. Activity of FAME was determined by combining $700 \mu \mathrm{L}$ of $0.1 \mathrm{M}$ sodium phosphate buffer $(\mathrm{pH}=6)$ with $250 \mu \mathrm{L}$ of culture supernatant and $50 \mu \mathrm{L}$ oleic acid $(4 \mathrm{mg} / \mathrm{mL}$ butanol) and incubating the solution for $20 \mathrm{~min}$ at $37^{\circ} \mathrm{C}$ with gentle shaking at $100 \mathrm{rpm}$. The reaction was terminated immediately by adding $19 \mathrm{~mL}$ chloroform:methanol $(2: 1 \mathrm{v} / \mathrm{v})$. An internal standard containing butyl stearate $(100 \mu \mathrm{L}$ added from stock of $0.5 \mathrm{mg} / \mathrm{mL}$ of chloroform) was used to quantify the amount of oleic acid esterified to butyl oleate. Lipids were extracted using the Folch procedure [24] and butyl esters quantified. Samples were analyzed using gas chromatography (Agilent Technologies $6890 \mathrm{~N}$ GC, California) equipped with a $30 \mathrm{~m} \mathrm{x}$ $0.25 \mathrm{~mm}$ with $0.15 \mu \mathrm{m}$ film DB-17HT capillary column (Agilent J\&W Scientific, California) with programmed temperature runs using hydrogen as the carrier gas. The oven temperature was initially $100^{\circ} \mathrm{C}$ and then increased $1.5^{\circ} \mathrm{C} / \mathrm{min}$ until $165^{\circ} \mathrm{C}$ and then held constant for $45 \mathrm{~min}$. The temperature was then ramped at $30^{\circ} \mathrm{C} / \mathrm{min}$ until $350^{\circ} \mathrm{C}$. Injection port temperature was at $200^{\circ} \mathrm{C}$. One $\mu \mathrm{L}$ of each sample was injected and the split ratio was $5: 1$ with flow rate held constant at $5 \mathrm{~mL} / \mathrm{min}$. Butyl oleate and butyl stearate (internal standard) peaks were detected with a flame ionization detector identified using standards and the area of the peaks quantified and used to calculate the percent of oleic acid esterified in each sample. Controls included TSB with no added bacteria in place of culture supernatant, and the phosphate buffer alone plus butanol and oleic acid to ensure the product did not form spontaneously.

\section{Lipase assay}

Lipase activity at each time point was determined by adding $50 \mu \mathrm{l}$ bacterial supernatant to $1 \mathrm{~mL}$ of lipase assay reagent $(10 \mathrm{mM}$ para-nitrophenyl palmitate, $0.1 \%$ Triton X-100 in ethanol) [25]. The reaction was 
Table 2 List of strains used in this study

\begin{tabular}{|c|c|c|}
\hline Species & Strain & $\begin{array}{l}\text { Source or } \\
\text { reference }\end{array}$ \\
\hline Escherichia coli & TOP10 & $\begin{array}{l}\text { Invitrogen, } \\
\text { Carlsbad, CA }\end{array}$ \\
\hline Escherichia coli & ATCC25922 & ATCC25922 \\
\hline Streptococcus uberis & ATCC27958 & ATCC27958 \\
\hline S. aureus & RN6390 & NCTC $8325-4^{*}$ \\
\hline S. aureus & MN8 & {$[20]^{*}$} \\
\hline S. aureus & Newman & {$[21]^{*}$} \\
\hline S. aureus & USA300 & {$[22]^{*}$} \\
\hline S. aureus & Novel & [23] \\
\hline S. aureus & Newbould 305 & ATCC29740 \\
\hline S. capitis & 240 & [12] \\
\hline S. caprae & 21 & [12] \\
\hline S. caprae & 208 & [12] \\
\hline S. caprae & 253 & [12] \\
\hline S. chromogenes & 1 & [12] \\
\hline S. chromogenes & 14 & [12] \\
\hline S. chromogenes & 61 & [12] \\
\hline S. chromogenes & 68 & [12] \\
\hline S. chromogenes & 74 & [12] \\
\hline S. chromogenes & 100 & [12] \\
\hline S. chromogenes & 105 & [12] \\
\hline S. chromogenes & 111 & [12] \\
\hline S. chromogenes & 133 & [12] \\
\hline S. chromogenes & 136 & [12] \\
\hline S. chromogenes & 159 & [12] \\
\hline S. chromogenes & 184 & [12] \\
\hline S. chromogenes & 207 & [12] \\
\hline S. chromogenes & 232 & [12] \\
\hline S. chromogenes & 267 & [12] \\
\hline S. epidermidis & 28 & [12] \\
\hline S. epidermidis & 35 & [12] \\
\hline S. equorum & 117 & [12] \\
\hline S. gallinarum & 196 & [12] \\
\hline S. haemolyticus & 20 & [12] \\
\hline S. haemolyticus & 39 & [12] \\
\hline S. haemolyticus & 95 & [12] \\
\hline S. haemolyticus & 98 & [12] \\
\hline S. haemolyticus & 141 & [12] \\
\hline S. haemolyticus & 180 & [12] \\
\hline S. haemolyticus & 247 & [12] \\
\hline S. haemolyticus & 275 & [12] \\
\hline S. hominis & 260 & [12] \\
\hline S. hyicus & 120 & [12] \\
\hline S. hyicus & 154 & [12] \\
\hline
\end{tabular}

Table 2 List of strains used in this study (Continued)

\begin{tabular}{lcc}
\hline S. hyicus & 155 & {$[12]$} \\
S. sciuri & 71 & {$[12]$} \\
S. sciuri & 99 & {$[12]$} \\
S. simulans & 23 & {$[12]$} \\
S. simulans & 112 & {$[12]$} \\
S. simulans & 125 & {$[12]$} \\
S. simulans & 181 & {$[12]$} \\
S. simulans & 250 & {$[12]$} \\
S. succinus & 261 & {$[12]$} \\
S. succinus & 110 & {$[12]$} \\
S. xylosus & 101 & {$[12]$} \\
S. xylosus & 113 & {$[12]$} \\
S. xylosus & 161 & {$[12]$} \\
S. xylosus & 183 & {$[12]$} \\
S. xylosus & 200 & {$[12]$} \\
S. xylosus & 246 & {$[12]$} \\
${ }^{*}$ kindly supplied by Drs. G.A. Bohach and K.S. Seo (Mississippi State \\
University, Mississippi). & &
\end{tabular}

incubated at $37^{\circ} \mathrm{C}, 300 \mathrm{rpm}$ for $40 \mathrm{~min}$. Absorbance was measured at $405 \mathrm{~nm}$ on a Wallac Victor2 plate reader (PerkinElmer, Turku, Finland). A standard curve was developed using dilutions of a supernatant from a S. aureus RN6390 24 h culture.

\section{Somatic Cell Count}

Milk samples at room temperature within $4 \mathrm{~h}$ postcollection were used. SCC was determined in triplicate using the DeLaval cell counter (DeLaval International AB, Tumba, Sweden) [26]. A cassette containing propidium iodide as the fluorescent stain was used to collect $60 \mu \mathrm{l}$ milk. The sample was exposed to an LED light source that causes the cell nuclei to give fluorescent signals which were subsequently recorded as SCC in milk.

\section{Statistics}

Data were analyzed by Student's $t$-test, SAS 9.2, to determine the threshold of FAME activity and lipase activity compared with negative controls. Significant and detectable activity was declared when FAME or lipase activity was different $(P<0.05)$ from both negative controls.

\section{Abbreviations}

CFU: Colony forming units; CNS: Coagulase-negative staphylococci; FAME: Fatty acid modifying enzyme; OD: Optical density; SCC: Somatic cell count; SD: Standard deviation; TSA: Tryptic soy agar; TSB: Tryptic soy broth.

Competing interests

The authors declare that they have no competing interests.

\section{Authors' contributions}

TL and MAM conceived the study. JYP and LKF identified and provided the CNS strains used in this study. TL, JYP, and KP carried out the experiments. 
TL analyzed the results. TL and MAM drafted the manuscript. Additionally, all authors have read and approved the final manuscript.

\section{Acknowledgements}

We thank Drs. G.A. Bohach and K.S. Seo (Mississippi State University, Mississippi, USA) for providing some S. aureus strains used in the experiments. This study was supported by the National Institutes of Health and the National Center for Research Resources Center of Biomedical Research Excellence (COBRE) grant \#P20 RR15587, by the Idaho Agricultural Experiment Station, and the United Dairymen of Idaho.

\section{Author details}

'Department of Biological Sciences, University of Idaho, Moscow, USA. 2Department of Animal and Veterinary Sciences, University of Idaho, Moscow, USA. ${ }^{3}$ Department of Veterinary Clinical Science, Washington State University, Pullman, USA. ${ }^{4}$ Department of Basic Sciences, Mississippi State University, Mississippi State, USA.

Received: 1 February 2012 Accepted: 8 June 2012

Published: 22 June 2012

\section{References}

1. Mortensen JE, Shryock TR, Kapral FA: Modification of bacterial fatty acids by an enzyme of Staphylococcus aureus. J Med Microbiol 1992, 36(4):293-298

2. Dye ES, Kapral FA: Characterization of a bactericidal lipid developing within staphylococcal abscesses. Infect Immun 1981, 32(1):98-104.

3. Kapral FA, Smith S, Lal D: The esterification of fatty acids by Staphylococcus aureus fatty acid modifying enzyme (FAME) and its inhibition by glycerides. J Med Microbiol 1992, 37(4):235-237.

4. Long JP, Hart J, Albers W, Kapral FA: The production of fatty acid modifying enzyme (FAME) and lipase by various staphylococcal species. J Med Microbiol 1992, 37:232-234

5. Chamberlain NR, Brueggemann SA: Characterisation and expression of fatty acid modifying enzyme produced by Staphylococcus epidermidis. J Med Microbiol 1997, 46(8):693-697.

6. Middleton JR, Fox LK, Smith TH: Management strategies to decrease the prevalence of mastitis caused by one strain of Staphylococcus aureus in a dairy herd. J Am Vet Med Assoc 2001, 218(10):1581-1582.

7. Dufour P, Jarraud S, Vandenesch F, Greenland T, Novick RP, Bes M, Etienne J, Lina G: High genetic variability of the agr locus in Staphylococcus species. J Bacteriol 2002, 184(4):1180-1186.

8. Chamberlain NR, Imanoel B: Genetic regulation of fatty acid modifying enzyme from Staphylococcus aureus. J Med Microbiol 1996, 44(2):125-129.

9. Cheung AL, Bayer AS, Zhang G, Gresham H, Xiong Y: Regulation of virulence determinants in vitro and in vivo in Staphylococcus aureus. FEMS Immunol Med Microbiol 2004, 40(1):1-9.

10. Palma M, Cheung AL: $\sigma^{B}$ activity in Staphylococcus aureus is controlled by RsbU and an additional factor(s) during bacterial growth. Infect Immun 2001, 69(12):7858-7865.

11. Rosenstein R, Gotz F: Staphylococcal lipases: Biochemical and molecular characterization. Biochimie 2000, 82(11):1005-1014.

12. Park JY, Fox LK, Seo KS, McGuire MA, Park YH, Rurangirwa FR, Sischo WM, Bahach GA: Comparison of phenotypic and genotypic methods for the species identification of coagulase-negative staphylococcal isolates from bovine intramammary infections. Vet Microbiol 2011, 147(1-2):142-148.

13. Månsson HL: Fatty acids in bovine milk fat. Food Nutr Res 2008, 52:1-3.

14. Barton GM: A calculated response: control of inflammation by the innate immune system. J Clin Invest 2008, 118(2):413-420.

15. Barunum DA, Newbould FHS: The use of the California mastitis test for the detection of bovine mastitis. Can Vet J 1961, 2(3):83-90.

16. Rollof J, Braconier JH, Soderstrom C, Milsson-Ehle P: Interference of Staphylococcus aureus lipase with human granulocyte function. Eur J Clin Microbiol Infect Dis 1988, 7(4):505-510.

17. Kuroda M, Nagasaki S, Ito R, Ohta T: Sesquiterpene farnesol as a competitive inhibitor of lipase activity of Staphylococcus aureus. FEMS Micro Lett 2007, 273(1):28-34.

18. Wunder $C$, Churin $Y$, Winau F, Warnecke $D$, Vieth $M$, Lindner B, Zahringer $U$, Mollenkopf $\mathrm{H}-\mathrm{J}$, Heinz E, Meyer TF: Cholesterol glucosylation promotes immune evasion by Helicobacter pylori. Nature Med 2006, 12(9):1030-1038.
19. Desbois AP, Smith VJ: Antibacterial free fatty acids: activities, mechanisms of action and biotechnological potential. Appl Microbiol Biotechnol 2010, 85(6):1629-1642.

20. Bohach GA, Kreiswirth BN, Novick RP, Schlievert PM: Analysis of toxic shock syndrome isolates producing staphylococcal enterotoxins $B$ and $C 1$ with use of Southern hybridization and immunologic assays. Rev Infect Dis 1989, 11(Suppl 1):S75-S81.

21. Duthie ES, Lorenz LL: Staphylococcal coagulase: mode of action and antigenicity. J Gen Microbiol 1952, 6(1-2):95-107.

22. Tenover FC, McDougal LK, Goering RV, Killgore G, Projan SJ, Patel JB, Dunman PM: Characterisation of a strain of community-associated methicillin-resistant Staphylococcus aureus widely disseminated in the United States. J Clin Microbiol 2006, 44(1):108-118.

23. Smith TH, Fox LK, Middleton JR: Outbreak of mastitis caused by one strain of Staphylococcus aureus in a closed dairy herd. J Am Vet Med Assoc 1998, 212(4):553-556.

24. Lees M, Folch J, Stanley GH, Carr S: A simple procedure for the preparation of brain sulphatides. J Neurochem 1959, 4(1):9-18.

25. Teng $Y, X u$ Y: A modified para-nitrophenyl palmitate assay for lipase synthetic activity determination in organic solvent. Anal Biochem 2007, 363(2):297-299.

26. Gonzalo C, Linage B, Carriedo JA, de la Fuente F, San Primitivo F: Evaluation of the overall accuracy of the DeLaval cell counter for somatic cell counts in ovine milk. J Dairy Sci 2006, 89(12):4613-4619.

27. Jensen RG: The composition of bovine milk lipids: January 1995 to December 2000. J Dairy Sci 2002, 85(2):295-350.

28. Auldist MJ, Hubble IB: Effects of mastitis on raw milk and dairy products. Austral J Dairy Technol 1998, 53(1):28-36.

doi:10.1186/1756-0500-5-323

Cite this article as: Lu et al:: Characterization of fatty acid modifying enzyme activity in staphylococcal mastitis isolates and other bacteria. BMC Research Notes 2012 5:323.

\section{Submit your next manuscript to BioMed Central and take full advantage of:}

- Convenient online submission

- Thorough peer review

- No space constraints or color figure charges

- Immediate publication on acceptance

- Inclusion in PubMed, CAS, Scopus and Google Scholar

- Research which is freely available for redistribution 